\title{
DESIGNATION OF THE TROPOSPHERE RADIO REFRACTIVITY FOR THE AREA OF THE MILITARY AERODROME IN DĘBLIN
}

\author{
Określenie wskaźników refrakcji troposferycznej dla \\ obszaru lotniska wojskowego w Dęblinie
}

\begin{abstract}
The radio refractivity is one of major parameters in troposphere monitoring over a selected military aerodrome. The paper makes an in-depth analysis and description of the results of radio refractivity of the troposphere zone. The radio refractivity of the troposphere zone was estimated for the area of the military aerodrome EPDE in Deblin, Poland. The radio refractivity of the troposphere zone was calculated using empirical troposphere models for the GNSS satellite technique as well as real meteorological data from the SYNOP message. In the paper, the authors demonstrate the results of wet, hydrostatic and total radio refractivity of the troposphere zone for EPDE military aerodrome. The SA and UNB3m models were applied in numerical computations of troposphere refractivity in an annual period.
\end{abstract}

Keywords: troposphere, meteorological data, refractivity, military aerodrome

Streszczenie: Refrakcyjność fal radiowych jest jednym z głównych parametrów monitorowania troposfery na wybranym lotnisku wojskowym. W artykule dokonano pogłębionej analizy $i$ opisu wyników załamania radiowego $w$ warstwie troposfery. Refrakcyjność radiowa warstwy troposfery oszacowano dla obszaru lotniska wojskowego EPDE w Dęblinie. Refrakcyjność radiowa warstwy troposfery została obliczona przy użyciu empirycznych modeli troposfery dla techniki satelitarnej GNSS, a także rzeczywistych danych meteorologicznych z depeszy SYNOP. W artykule autorzy przedstawiaja wyniki mokrej, hydrostatycznej $i$ całkowitej refrakcji radiowej warstwy troposfery dla lotniska wojskowego EPDE. Modele SA i UNB3m zastosowano $w$ obliczeniach numerycznych refrakcji troposfery $w$ okresie rocznym.

Słowa kluczowe: technika satelitarna GNSS, empiryczne modele troposfery, depesza SYNOP, depesza TAF, dane meteorologiczne 


\section{Introduction}

For the sake of the GNSS implementation techniques in navigation, the Earth's atmosphere has been divided into two parts: dispersive (commonly referred to as ionosphere) and non-dispersive (commonly referred to as troposphere). In case of ionosphere, the GNSS signals are delayed for code measurements and accelerated for phase measurements. It must be noted that code measurements are propagating at group velocity, while phase measurements at phase velocity, respectively. The coefficient of ionospheric refraction for group velocity is always greater than unity $\left(N_{g_{l}}>1\right)$, whereas for the phase speed, it is less than unity $\left(N_{p h}<1\right)$ [9]. On the other hand, when the GNSS signal passes through a non-dispersive (neutral) layer, the coefficient of refraction of the medium is always greater than unity $\left(N_{\text {trop }}>1\right)$, therefore the values of tropospheric delay are always positive. Additionally, nondispersion of the troposphere medium makes the coefficient of refraction of the troposphere zone independent of the carrier frequency, and thus it becomes impossible to formulate a mathematical expression (i.e. linear combination) which reduces the effect of tropospheric delay [2]. In practice, in the numerical calculations with regard to the troposphere, the refractivity index is used, instead of coefficient of refraction. It needs to be stressed that the coefficient of refraction of the troposphere zone is close to unity. The total value of the refractivity index is a sum of the refractivity index of the hydrostatic part and the refractivity index of the wet part of the troposphere. It is worth adding that refraction of the hydrostatic part of the troposphere constitutes approximately $90 \%$ of the total refractivity index. On the other hand, refraction of the wet part of the troposphere constitutes approximately $10 \%$ of the total refractivity index [7].

The main aim of this study is to present the results of the troposphere refractivity index for the hydrostatic and wet parts. The parameters of the troposphere refractivity index have been determined for the area of Dęblin military aerodrome (EPDE), situated in south-eastern Poland. In particular, the troposphere refractive indexes were determined for the GNSS reference station, located on the grounds of the military aerodrome EPDE. In addition, the troposphere refractive indexes were determined by means of real meteorological data from the SYNOP message for the station Deblin/Irena 12490.

\section{Materials and methods}

The general formula for the total value of the troposphere refractivity index, in accordance with the ITU recommendation, is expressed as below [1]: 


$$
\left\{\begin{array}{c}
N_{\text {trop }}=N_{\text {hyd }}+N_{\text {wet }} \\
N_{\text {trop }}=77.6 \cdot(P / T)+3.73 \cdot 10^{5} \cdot\left(\mathrm{e} / \mathrm{T}^{2}\right)
\end{array}\right.
$$

where:

$N_{\text {trop }}$ - total value of troposphere refractivity, $N_{\text {hyd }}$ - troposphere refractivity of hydrostatic part, $N_{\text {wet }}$ - troposphere refractivity of wet part, $P$ - air pressure, $T$ - air temperature, $e-$ partial water vapour pressure.

In the framework of the research experiment, two numerical tests were made, aimed at specifying the troposphere refractive indexes for the hydrostatic part and wet part. In the first experimental test, the troposphere refractive indexes of were determined for the GNSS reference station, located on the grounds of the military aerodrome EPDE. On the GNSS reference station, the geodetic receiver Topcon HiperPro was installed. Its aim was to collect, on a continuous basis, satellite observations of the GPS and GLONASS navigation systems [6]. In the experimental test, empirical models of the troposphere were exploited in order to determine the basic meteorological parameters (temperature, pressure and water vapour pressure). The designated meteorological parameters were referenced to the coordinates of the reference station REF1 in Dęblin, as below: Latitude: 51 $33^{\circ}$ 19.92606" N; Longitude: $21^{\circ} 52^{\prime}$ 08.72275" E; ellipsoidal height: $152.069 \mathrm{~m}$. For the sake of determining the values of meteorological parameters ( $T, p, e)$, two empirical models of the troposphere were used, see below model SA and model UNB3m. The meteorological parameters (temperature, pressure and the water vapour pressure in the empirical SA model were determined on the basis of the mathematical formulas as below $[4,5]$ :

$$
\left\{\begin{array}{c}
T=T_{0}-0.0065 \cdot\left(h-h_{0}\right) \\
P=P_{0} \cdot\left(1-0.000026 \cdot\left(h-h_{0}\right)^{5.225}\right) \\
e=(R H / 100) \cdot 6.1121 \cdot \exp (17.502 \cdot T c / 240.97+T c)
\end{array}\right.
$$

where:

$T$ - temperature at required height in SA model, unit $[\mathrm{K}] ; T_{0}$ - mean temperature in SA model, e. g. $18^{\circ} \mathrm{C}(291 \mathrm{~K})$, unit $[\mathrm{K}] ; P$ - pressure at required height in SA model, unit $[\mathrm{hPa}] ; P_{0}$ - mean pressure in $\mathrm{SA}$ model, e. g. $1013.25 \mathrm{hPa}$, unit $[\mathrm{hPa}] ; R H-$ relative humidity at required height in SA model, unit [\%]; $h$ - required height, unit $[\mathrm{m}] ; h_{0}$ - the sea level, e. g. $0 \mathrm{~m}$, unit $[\mathrm{m}] ; e$ - partial water vapour pressure at 
required height in $\mathrm{SA}$ model, unit $[\mathrm{hPa}] ; T c$ - temperature at required height in $\mathrm{SA}$ model, $T c=T$, unit $\left[{ }^{\circ} \mathrm{C}\right]$.

The meteorological parameters (temperature, pressure and the water vapour pressure in the empirical model UNB3m were determined on the basis of the mathematical formulas as below (8):

$$
\left\{\begin{array}{c}
T=T_{0}-\beta_{0} \cdot h \\
P=P_{0} \cdot\left(T / T_{0}\right)^{\left(g / R \cdot \beta_{0}\right)} \\
e=(R H / 100) \cdot e_{S} \cdot f_{W}
\end{array}\right.
$$

where:

$T$ - temperature at required height in UNB3m model, unit $[\mathrm{K}] ; T_{0}$ - interpolated temperature, the temperature $T_{0}$ is interpolated based on day of year, receiver latitude, average and seasonal variation of temperature from previous years, unit $[\mathrm{K}] ; P$ - pressure at required height in UNB3m model, unit $[\mathrm{hPa}] ; P_{0}$ - interpolated pressure, the pressure $P_{0}$ is interpolated based on day of year, sensor latitude, average and seasonal variation of pressure from previous years, unit [hPa]; $R H-$ interpolated relative humidity in UNB3m model, the relative humidity $R H$ is interpolated based on day of year, receiver latitude, average and seasonal variation of relative humidity from previous years, unit $[\%] ; h$ - required height, unit $[\mathrm{m}]$; $g$ - standard acceleration of gravity, unit $\left[\mathrm{m} / \mathrm{s}^{2}\right] ; \beta_{0}$ - interpolated temperature lapse rate, the temperature lapse rate $\beta_{0}$ is interpolated based on day of year, receiver latitude, average and seasonal variation of temperature lapse rate from previous years, unit $[\mathrm{K} / \mathrm{m}] ; \lambda_{0}$ - interpolated water vapor lapse rate, the water vapor lapse rate $\lambda_{0}$ is interpolated based on day of year, receiver latitude, average and seasonal variation of water vapor lapse rate from previous years, unit [-]; $R$ - gas constant for dry air, unit $[\mathrm{J} / \mathrm{K} \cdot \mathrm{kg}] ; e$ - partial water vapour pressure at required height in $\mathrm{UNB} 3 \mathrm{~m}$ model, unit $[\mathrm{hPa}] ; e_{S}-$ saturation water vapour, unit $[\mathrm{hPa}] ; f_{W}-$ enhancement factor, unit [-].

\section{Results and discussion}

The upper part of fig. 1 shows the values of troposphere refractive indexes for the hydrostatic part, on the basis of empirical SA and UNB3m models. The values of the troposphere refractive indexes for the hydrostatic part were presented on an annual basis for the period of 01.01.2010-31.12.2010. It should be noted that the troposphere refractivity index for the hydrostatic part, for the SA model, is constant in the annual 
cycle and equals 266.1 units. The empirical SA model assumes a constant course of the troposphere refractivity index for the hydrostatic part, for spring, summer, autumn and winter. The value of the troposphere refractivity index for the hydrostatic part, for the UNB3m model, in an annual cycle, changes periodically. The highest values of the troposphere refractivity index for the hydrostatic part, for the UNB3m model, can be noticed in the winter period, and the lowest in the summer period. In particular, the maximum value of the troposphere refractivity index for the hydrostatic part, for the UNB3m model, equals 291.9 units, whereas the minimum value is equal to 265.8 units, respectively. In addition, the median value for the troposphere refractivity index for the hydrostatic part, in the model UNB3m, equals 278.3 units. In the UNB3m model, there are two maxima of troposphere refractive indexes, for the hydrostatic part, i.e. in the period of January and February, as well as in December. Moreover, at the turn of June and July there is the minimum value of the troposphere refractivity index for the hydrostatic part, in the UNB3m model. In spring, it is possible to observe a decrease of approximately 30 units of the troposphere refractivity index for the hydrostatic part, in the model UNB3m. In autumn, there is an increase by over 30 units of the troposphere refractivity index for the hydrostatic part, in the model UNB3m.
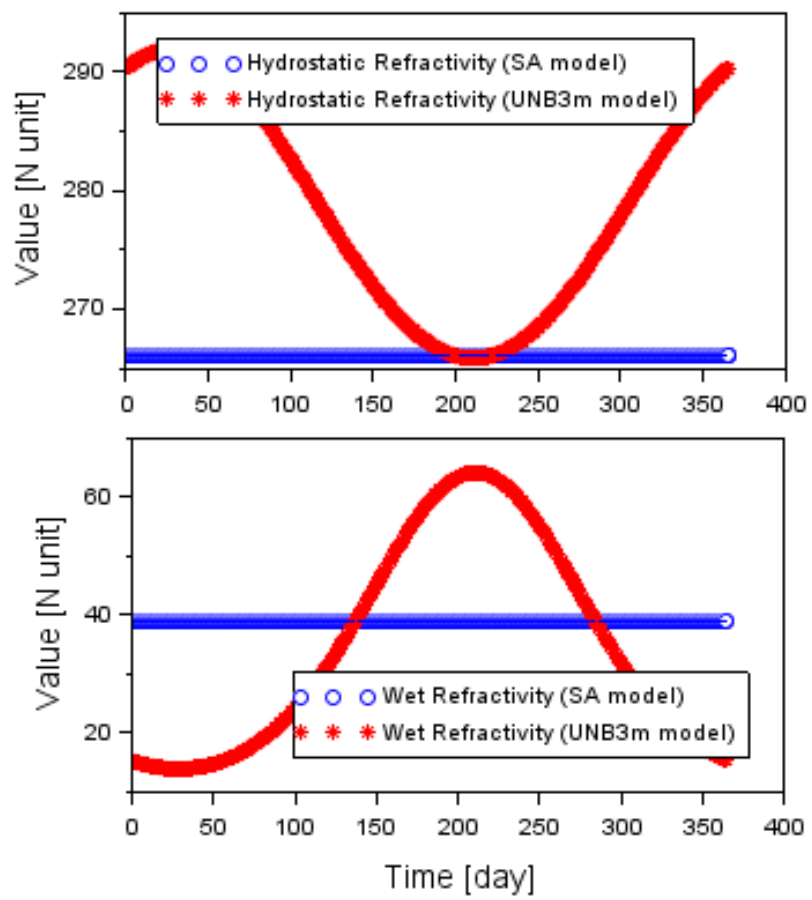

Fig. 1. The hydrostatic and wet refractivity for REF1 GNSS station based on SA and UNB3m models 
Also, in the bottom part of fig. 1 there are values of the troposphere refractive indexes for the wet part, on the basis of the empirical models SA and UNB3m. The values of the troposphere refractive indexes for the wet part were presented on an annual basis. It should be noted that the troposphere refractivity index for the wet part, for the SA model, is constant in an annual cycle and equals approximately 39 units. The empirical SA model assumes a constant course of the troposphere refractivity index for the wet part for spring, summer, autumn and winter. The value of the troposphere refractivity index for the wet part, for the UNB3m model, in an annual cycle, changes periodically. The highest values of the troposphere refractivity index for the wet part, for the UNB3m model, can be noticed in the summer period, and the lowest in the winter period. In particular, the maximum value of the troposphere refractivity index for the wet part, for the UNB3m model, equals 54.1 units, whereas the minimum value is equal to 13.8 units, respectively. In addition, the median value for the troposphere refractivity index for the wet part, in the model UNB3m, equals approximately 31 units. In the UNB3m model, there are two minima of troposphere refractive indexes, for the wet part, i.e. in the period of January and February, as well as December. Moreover, at the turn of June and July there is the minimum of the troposphere refractivity index for the wet part, in the UNB3m model. In spring, it is possible to observe an increase of approximately 50 units of the troposphere refractivity index for the wet part, in the model UNB3m. In autumn, there is a decrease by over 50 units of the troposphere refractivity index for the wet part, in the model UNB3m.

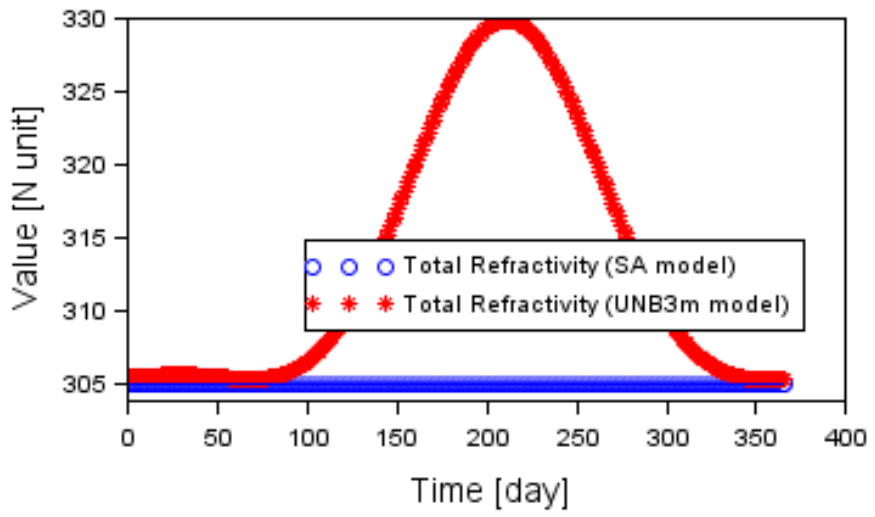

Fig. 2. The total refractivity for REF1 GNSS reference station based on SA and UNB3m models

Figure 2 shows the values of the total refractivity index of the troposphere on the basis of empirical models SA and UNB3m. The values of the total refractivity index of the troposphere for SA and UNB3m models are presented in an annual 
cycle. It should be noted that the troposphere refractivity index, for the SA model, is constant in an annual cycle and equals approximately 305.1 units. The empirical SA model assumes a constant course of the troposphere refractivity index for spring, summer, autumn and winter. The value of the total refractivity index of the troposphere for the UNB3m model, in an annual cycle, changes periodically in time. The highest values of the troposphere refractivity index, for the UNB3m model, can be noticed in the summer period, and the lowest in the winter period. In particular, the maximum value of the total refractivity index of the troposphere, for the UNB3m model, equals 329.9 units, whereas the minimum value is equal to 305.4 units, respectively. In addition, the median value for the total refractivity index of the troposphere, in the model UNB3m, equals approximately 309.3 units. In the UNB3m model, there are two minima of total refractive indexes of the troposphere, i.e. in the period of January, February and March and in December. Moreover, at the turn of June and July, there is the maximum of the total refractivity index of the troposphere, in the UNB3m model. In spring, it is possible to observe an increase of approximately 25 units of the total refractivity index of the troposphere, in the model UNB3m. In autumn, there is a decrease by over 25 units of the total refractivity index of the troposphere, in the model UNB3m.
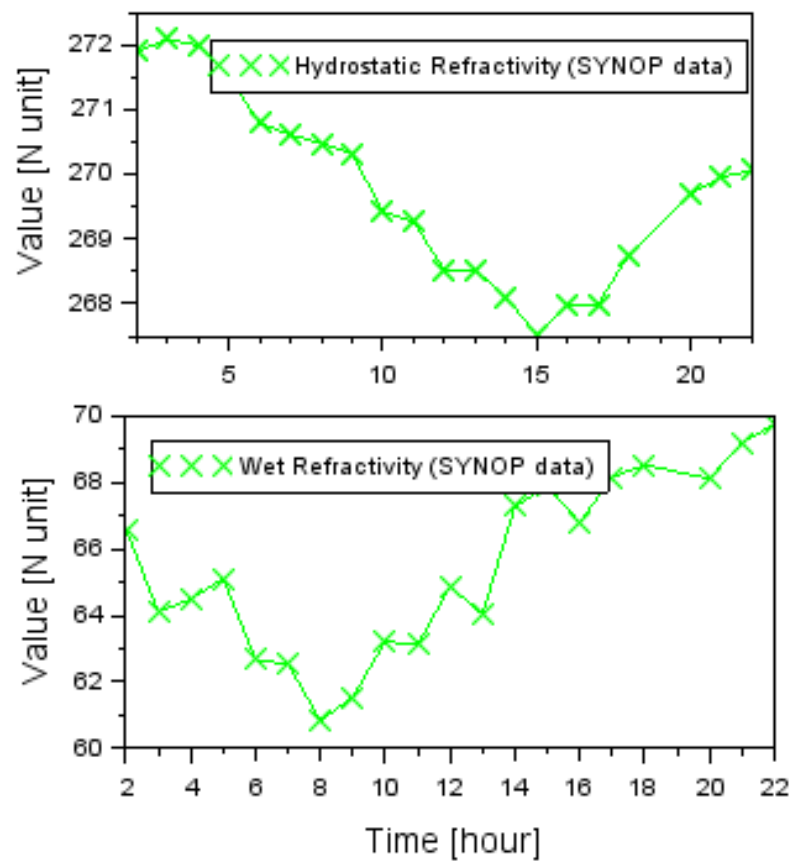

Fig. 3. The hydrostatic and wet refractivity for SYNOP Deblin/Irena 12490 station 
In the second research test, the authors made an accurate designation of troposphere refractive indexes for the hydrostatic part and wet part, using meteorological data, registered by the SYNOP station Deblin/Irena 12490. The SYNOP Deblin/Irena 12490 station is localized in the vicinity to the military aerodrome EPDE in Dęblin. The SYNOP station Deblin/Irena 12490 is a civil aviation meteorological facility, owned by the Institute of Meteorology and Water Management, based in Warsaw. The geographical coordinates of Deblin/ Irena,12490, SYNOP station are as follows: 51 $33^{\prime} \mathrm{N}$ Latitude; $21051^{\prime} \mathrm{E}$ Longitude; $124 \mathrm{~m}$ height above the sea level. Exemplary numerical computations of troposphere refractive indexes for the hydrostatic and wet parts were made for 1 June 2010. It must be mentioned that the troposphere refractive indexes for the hydrostatic and wet parts were determined for the needs of a flight experiment, executed on this day, within the implementation of the GNSS satellite technique, for an approach to landing procedures performed by a Cessna 172 aircraft, at the military aerodrome in Dęblin [3]. The determination of the state of the troposphere on this day was essential to maintain weather cover for the air operations, executed on the grounds of the military aerodrome EPDE in Dęblin. The meteorological data for the SYNOP station Deblin/Irena 12490 were generated from the online service WWW.OGIMET.COM [10].

The upper part of fig. 3 depicts the daily change in the troposphere refractivity index for the hydrostatic part, determined on the basis of data recorded by the meteorological sensor at the SYNOP station Deblin/Irena 12490 on 1 June 2010. The minimum value of the troposphere refractivity index for the hydrostatic part on 1 June 2010 amounted to 267.5 units at 15:00:00 UTC, whereas maximum was 272.1 units at 03:00:00 UTC. Besides, the mean value of the troposphere refractivity index for the hydrostatic part on this day amounted to 269.7 units, while the median was equal to 269.8 units. From 02 UTC to 15 UTC, it is clear that the troposphere refractivity index for the hydrostatic part was constantly decreasing, on the basis of meteorological data from the SYNOP message. On the other hand, from 15 UTC to 22 UTC it is possible to draw a conclusion that the troposphere refractivity index for the hydrostatic part is constantly growing, on the basis of meteorological data from the SYNOP message. It should be noted that at 01,19 and 23 hours, the meteorological sensor on the SYNOP station Deblin/Irena 12490 did not record any numerical data relating to the parameters of the troposphere ( $\mathrm{p}$, $\mathrm{T}, \mathrm{e}$ ), thus it was not possible to determine the troposphere refractivity index for the hydrostatic part. The bottom part of Figure 3 shows the daily change in the troposphere refractivity index for the wet part, determined on the basis of data recorded by the meteorological sensor at the SYNOP station Deblin/Irena 12490 on 1 June 2010. The minimum value of the troposphere refractivity index for the 
wet part on 1 June 2010 amounted to 60.8 units at 08:00:00 UTC, whereas the maximum value was 69.8 units at 22:00:00 UTC. Moreover, the mean value of the troposphere refractivity index, for the wet part, on this day, equalled 65.4 units, with the median being equal to 65 units. From 02 UTC until 08 UTC, it is clear that the troposphere refractivity index for the wet part is constantly decreasing, on the basis of meteorological data from the SYNOP message. On the other hand, from 08 UTC to 22 UTC, it is possible to conclude that the refractivity index of the troposphere for the wet part is constantly growing, on the basis of meteorological data from the SYNOP message. It should be noted that at 01,19 and 23 hours, the meteorological sensor on the SYNOP station Deblin/Irena 12490 did not record any numerical data relating to the parameters of the troposphere $(P, T, e)$, and thus it was not possible to determine the troposphere refractivity index for the wet part.

The bottom part of fig. 3 shows the daily change in the total refractivity index of the troposphere, determined on the basis of data recorded by the meteorological sensor at the SYNOP station Deblin/Irena 12490 on 1 June 2010. The minimum value of the total refractivity index of the troposphere on 1 June 2010 amounted to 331.3 units at 08:00:00 UTC, whereas the maximum value was 333.9 units at 22:00:00 UTC. Moreover, the mean value of the total refractivity index of the troposphere, on this day, equalled 335.2 units, with the median being equal to 335.4 units. From 02 UTC until 08 UTC, it is clear that the total refractivity index of the troposphere is constantly decreasing, on the basis of meteorological data from the SYNOP message. On the other hand, from 08 UTC to 22 UTC, it is possible to conclude that the total refractivity index of the troposphere is constantly growing, on the basis of meteorological data from the SYNOP message. It should be noted that at 01,19 and 23 hours, the meteorological sensor on the SYNOP station Deblin/Irena 12490 did not record any numerical data relating to the parameters of the troposphere $(p, T, e)$, and thus it was not possible to determine the total refractivity index of the troposphere.

Figure 4 shows the daily change in the total tropospheric refractive index, determined on the basis of data recorded by the meteorological sensor at the SYNOP Dęblin/Irena station 12490 on 01.06.2010. The minimum value of the total tropospheric refractive index on 01.06.2010 was 331.3 units at 08:00:00 UTC time, while the maximum value was 339.8 units at 22:00:00 UTC. In addition, the mean value of the total tropospheric refractive index on that day was 335.2 units, and the median is 335.4 units. From 02 UTC to 08 UTC it is clearly visible that the total tropospheric refractive index is constantly decreasing based on meteorological data from the SYNOP message. In turn, from 08.00 UTC to 22 UTC, it can be concluded that the total tropospheric refractive index is constantly increasing based on meteorological data from the SYNOP message. It should be noted that at 01,19 
and 23 the meteorological sensor at the SYNOP Dęblin/Irena 12490 station did not record any numerical data on the troposphere parameters $(p, T, e)$ and therefore it was not possible to determine the total tropospheric refractive index.

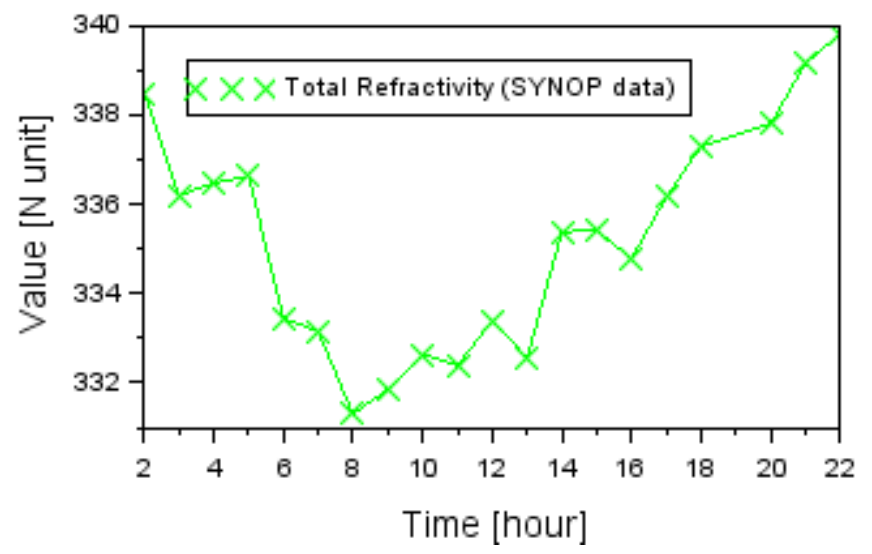

Fig. 4. The total refractivity for SYNOP Deblin/Irena 12490 station

\section{Conclusions}

The article presents the results of determining the troposphere refractive indexes for the military aerodrome EPDE in Dęblin. In particular, the article presents the results of the total value of troposphere refractivity indexes $N_{\text {trop }}$, troposphere refractivity of hydrostatic part indexes $N_{h y d}$, troposphere refractivity of the wet part indexes $N_{\text {hyd. }}$. The troposphere refractive indexes were determined on the basis of empirical tropospheric models and real meteorological data. In the case of empirical meteorological data, the tropospheric models SA and UNB3m were used. On the other hand, the real meteorological data $(T, p, e)$ were recorded by the SYNOP station Deblin/Irena 12490. In the calculations, the basic parameters, i.e. temperature, pressure and water vapour pressure were used.

\section{Acknowledgements}

The authors would like to thank the OGIMET service for the available meteorological data.

This paper has been supported by the Polish Air Force University, Faculty of Aeronautics, Department of Air Navigation. 


\section{References}

1. Adeyemi B., Emmanuel I.: Monitoring tropospheric radio refractivity over Nigeria using CM-SAT data derived from NOAA-15, 16 and 18 satellites. Indian Journal of Radio \& Space Physics. vol. 40, 2011.

2. Bosy J.: Precise processing of satellite GPS observations in local networks located in mountain areas. Wydawnictwo Akademii Rolniczej we Wrocławiu. Nr 522, 2005 (in Polish).

3. Ćwiklak J., Krasuski K., Jafernik H.: Designation the velocity of Cessna 172 aircraft based on GPS data in flight test. Proceedings of 23rd International Conference Engineering Mechanics 2017. Svratka, Czech Republic, 15-18 May 2017.

4. Dach R., Hugentobler U., Fridez P., Meindl M.: Bernese GPS software version 5.0. Astronomical Institute, University of Bern, 2007.

5. Ibeh G. F., Agbo G. A.: Estimation of tropospheric refractivity with artificial neural network at Minna, Nigeria. Global Journal of Science Frontier Research. Vol. 12, No. 1, Version 1.0 May 2012.

6. Krasuski K., Ćwiklak J., Jafernik H.: Verification of the precise position of the aircraft in air navigation based on the solution of the RTK-OTF technique. Journal of KONES. 2017, vol. 24, no. 4, DOI: 10.5604/01.3001.0010.3126.

7. Kruczyk M.: GNSS tropospheric delay and its issue in research on state of atmosphere. Prace Naukowe Geodezja. vol. 54, 2013 (in Polish).

8. Leandro R., Santos M., Langley R.: UNB Neutral Atmosphere Models: Development and Performance, Proceedings of ION NTM 2006, the 2006 National Technical Meeting of The Institute of Navigation, Monterey, California, 18-20 January 2006.

9. Schaer S.: Mapping and predicting the earth's ionosphere using global positioning system. Ph.D. thesis, Astronomy Institute, University Bern, Switzerland, 1999.

10. www.ogimet.com, current on 2019. 


\section{OKREŚLENIE WSKAŹNIKÓW REFRAKCJI TROPOSFERYCZNEJ DLA OBSZARU LOTNISKA WOJSKOWEGO W DĘBLINIE}

\section{Wprowadzenie}

Na potrzeby implementacji techniki satelitarnej GNSS w nawigacji, atmosfera ziemska została podzielona na dwie części: dyspersyjną (zwaną potocznie jonosferą) oraz niedyspersyjną (zwaną potocznie troposferą). W przypadku jonosfery sygnały GNSS ulegają opóźnieniu dla pomiarów kodowych oraz przyspieszeniu dla pomiarów fazowych. Warto zauważyć, iż pomiary kodowe rozchodzą się z prędkością grupową, zaś pomiary fazowe z prędkością fazową. Współczynnik refrakcji jonosferycznej dla prędkości grupowej jest zawsze większy od jedności $\left(N_{g r}>1\right)$, zaś dla prędkości fazowej mniejszy od jedności $\left(N_{p h}<1\right)$ [9]. Z kolei przy przechodzeniu sygnału GNSS przez warstwę niedyspersyjną (neutralną), współczynnik załamania ośrodka jest zawsze większy od jedności $\left(N_{\text {trop }}>1\right)$, co powoduje, iż wartości opóźnienia troposferycznego są zawsze dodatnie. Niedyspersyjność ośrodka troposfery powoduje dodatkowo, iż współczynnik refrakcji troposferycznej jest niezależny od częstotliwości fali nośnej, a zatem niemożliwe jest sformułowanie wyrażenia matematycznego (tj. kombinacji liniowej) redukującego efekt opóźnienia troposferycznego [2]. W praktyce $\mathrm{w}$ obliczeniach numerycznych dotyczący troposfery posługujemy się wskaźnikiem refrakcji, zamiast współczynnika refrakcji. Należy podkreślić, że współczynnik refrakcji dla troposfery jest bliski jedności. Całkowita wartość wskaźnika refrakcji jest sumą wskaźnika refrakcji części hydrostatycznej troposfery oraz wskaźnika refrakcji części mokrej troposfery. Warto dodać, refrakcja części hydrostatycznej troposfery stanowi ok. 90\% całkowitego wskaźnika refrakcji. Natomiast refrakcja części mokrej troposfery stanowi ok. 10\% całkowitego wskaźnika refrakcji [7].

Głównym celem prezentowanej pracy jest przedstawienie rezultatów wskaźnika refrakcji troposfery dla części hydrostatycznej i mokrej. Parametry wskaźnika refrakcji troposfery zostały określone dla obszaru lotniska wojskowego Dęblin (EPDE), położonego w południowo-wschodniej Polsce. W szczególności 
wskaźniki refrakcji troposferycznej wyznaczono dla stacji referencyjnej GNSS zlokalizowanej na terenie lotniska wojskowego EPDE. Ponadto wskaźniki refrakcji troposferycznej określono również $\mathrm{z}$ użyciem rzeczywistych danych meteorologicznych z depeszy SYNOP dla stacji Dęblin/Irena 12490.

\section{Materiały oraz metoda badawcza}

Ogólny wzór na całkowitą wartość wskaźnika refrakcji troposferycznej zgodnie z rekomendacją ITU przyjmuje postać [1]:

$$
\left\{\begin{array}{c}
N_{\text {trop }}=N_{\text {hyd }}+N_{\text {wet }} \\
N_{\text {trop }}=77.6 \cdot(P / T)+3.73 \cdot 10^{5} \cdot\left(\mathrm{e} / T^{2}\right)
\end{array}\right.
$$

gdzie:

$N_{\text {trop }}$ - całkowita refrakcja troposferyczna, $N_{\text {hyd }}$ - refrakcja troposferyczna dla części hydrostatycznej, $N_{\text {wet }}$ - refrakcja troposferyczna dla części mokrej, $P$ - ciśnienie powietrza, $T$ - temperatura powietrza, $e$ - częściowe ciśnienie pary wodnej.

W ramach eksperymentu badawczego wykonano dwa testy numeryczne mające na celu określenie wskaźników refrakcji troposferycznej dla części hydrostatycznej i mokrej. W pierwszym teście badawczym określono wskaźniki refrakcji troposferycznej dla stacji referencyjnej GNSS zlokalizowanej na terenie lotniska wojskowego EPDE w Dęblinie. Na stacji referencyjnej GNSS został zamontowany odbiornik geodezyjny Topcon HiperPro, który gromadził permanentnie obserwacje satelitarne z systemów nawigacyjnych GPS i GLONASS [6]. W teście badawczym wykorzystano empiryczne modele troposfery do określenia podstawowych parametrów meteorologicznych (temperatury, ciśnienia oraz prężności pary wodnej). Wyznaczane parametry meteorologiczne zostały odniesione do współrzędnych stacji referencyjnej REF1 w Dęblinie, jak poniżej: jak poniżej: Szerokość: 51³3'19,92606” N; Długość: 2152'08,72275” E; wysokość elipsoidalna: $152,069 \mathrm{~m}$. Na potrzeby wyznaczenia wartości parametrów meteorologicznych $(T, p, e)$ wykorzystano dwa empiryczne modele troposfery, jak poniżej: model SA i model UNB3m. Parametry meteorologiczne (temperatura, ciśnienie i prężność pary wodnej) w modelu empirycznym SA zostały określone na podstawie formuł matematycznych, jak poniżej $[4,5]$ : 


$$
\left\{\begin{array}{c}
T=T_{0}-0.0065 \cdot\left(h-h_{0}\right) \\
P=P_{0} \cdot\left(1-0.000026 \cdot\left(h-h_{0}\right)^{5.225}\right) \\
e=(R H / 100) \cdot 6.1121 \cdot \exp (17.502 \cdot T c / 240.97+T c)
\end{array}\right.
$$

gdzie:

$T$ - temperatura wyznaczana w modelu SA, jednostka $[\mathrm{K}] ; T_{0}$ - średnia temperatura w modelu SA, np. $18^{\circ} \mathrm{C}(291 \mathrm{~K})$, jednostka $[\mathrm{K}] ; P$ - ciśnienie wyznaczane w modelu SA, jednostka $[\mathrm{hPa}] ; P_{0}$ - średnie ciśnienie w modelu SA, np. 1013,25 hPa, jednostka [hPa]; $R H$ - wilgotność względna wyznaczana w modelu SA, jednostka [\%]; $h$ - określona wysokość, jednostka [m]; $h_{0}$ - poziom morza, np. $0 \mathrm{~m}$, jednostka $[\mathrm{m}] ; e$ - cząstkowe ciśnienie (prężność) pary wodnej, jednostka $[\mathrm{hPa}] ; T c$ - zadana temperatura w modelu SA, $T c=T$, jednostka $\left[{ }^{\circ} \mathrm{C}\right]$.

Parametry meteorologiczne (temperatura, ciśnienie i prężność pary wodnej) w modelu empirycznym UNB3m zostały określone na podstawie formuł matematycznych [8]:

$$
\left\{\begin{array}{c}
T=T_{0}-\beta_{0} \cdot h \\
P=P_{0} \cdot\left(T / T_{0}\right)^{\left(g / R \cdot \beta_{0}\right)} \\
e=(R H / 100) \cdot e_{S} \cdot f_{W}
\end{array}\right.
$$

gdzie:

$T$ - wyznaczana temperatura $\mathrm{w}$ modelu UNB3m, jednostka $[\mathrm{K}] ; T_{0}-$ interpolowana temperatura, temperatura $T_{0}$ jest interpolowana na podstawie dnia roku, szerokości geodezyjnej odbiornika, średniej i sezonowej zmiany temperatury z poprzednich lat, jednostka $[\mathrm{K}] ; P$ - wyznaczane ciśnienie w modelu UNB3m, jednostka $[\mathrm{hPa}] ; P_{0}-$ interpolowane ciśnienie, ciśnienie $P_{0}$ jest interpolowane na podstawie dnia roku, szerokości geodezyjnej odbiornika, średniej i sezonowej zmienności ciśnienia z poprzednich lat, jednostka [hPa]; $R H$-względna wilgotność w modelu UNB3m, jednostka [\%]; $R H_{0}$ - interpolowana wilgotność względna, wilgotność względna $R H_{0}$ jest interpolowana na podstawie dnia roku, szerokości geodezyjnej odbiornika, średniej i sezonowej zmienności wilgotności względnej z poprzednich lat, jednostka [\%]; $h$ - określona wysokość, jednostka $[\mathrm{m}] ; g-$ standardowe przyspieszenie grawitacyjne, jednostka $\left[\mathrm{m} / \mathrm{s}^{2}\right] ; \beta_{0}-$ interpolowana zmienność temperatury, współczynnik zmiany temperatury $\beta_{0}$ jest interpolowany na podstawie dnia roku, szerokości geodezyjnej odbiornika, średniej i sezonowej zmienności współczynnika zmiany temperatury z poprzednich lat, jednostka 
$[\mathrm{K} / \mathrm{m}] ; \lambda_{0}$ - interpolowana zmienność zawartości pary wodnej, współczynnik zmiany zawartości pary wodnej $\lambda_{0}$ jest interpolowany na podstawie dnia roku, szerokości geodezyjnej odbiornika, średniej i sezonowej zmienności współczynnika zmiany zwartości pary wodnej z poprzednich lat, jednostka [-]; $R$ - stała gazowa, jednostka $[\mathrm{J} / \mathrm{K} \cdot \mathrm{kg}]$; $e$ - cząstkowe ciśnienie pary wodnej $\mathrm{w}$ modelu UNB3m, jednostka $[\mathrm{hPa}] ; e_{S}-$ stan saturacji pary wodnej, jednostka $[\mathrm{hPa}] ; f_{W}-$ współczynnik bezwymiarowy, jednostka [-].

\section{Rezultaty badań oraz dyskusja}

W górnej części rys. 1 przedstawiono wartości wskaźników refrakcji troposferycznej dla części hydrostatycznej na podstawie empirycznych modeli SA i UNB3m. Wartości wskaźników refrakcji troposferycznej dla części hydrostatycznej zostały przedstawione w cyklu rocznym dla okresu 01.01.2010-31.12.2010. Należy zauważyć, że wskaźnik refrakcji troposferycznej dla części hydrostatycznej dla modelu SA jest stały w cyklu rocznym i wynosi 266,1 jednostek. Model empiryczny SA zakłada stały przebieg wskaźnika refrakcji troposferycznej dla części hydrostatycznej przez okres wiosenny, letni, jesienny i zimowy. Wartość wskaźnika refrakcji troposferycznej dla części hydrostatycznej dla modelu UNB3m w cyklu rocznym zmienia się periodycznie. Największe wartości wskaźnika refrakcji troposferycznej dla części hydrostatycznej dla modelu UNB3m są zauważane w okresie zimowym, zaś najmniejsze w okresie letnim. W szczególności wartość maksymalna wskaźnika refrakcji troposferycznej dla części hydrostatycznej dla modelu UNB3m wynosi 291,9 jednostek, zaś odpowiednio wartość minimalna jest równa 265,8 jednostek. Ponadto wartość mediany dla wskaźnika refrakcji troposferycznej dla części hydrostatycznej w modelu UNB3m wynosi 278,3 jednostek. W modelu UNB3m występują dwa maksima wskaźników refrakcji troposferycznej dla części hydrostatycznej, tj. w okresie styczeń i luty, oraz w okresie grudniowym. Ponadto na przełomie czerwca i lipca występuje minimum wskaźnika refrakcji troposferycznej dla części hydrostatycznej w modelu UNB3m. W okresie wiosennym występuje spadek o ok. 30 jednostek wartości wskaźnika refrakcji troposferycznej dla części hydrostatycznej w modelu UNB3m. W okresie jesiennym występuje wzrost o ponad 30 jednostek wartości wskaźnika refrakcji troposferycznej dla części hydrostatycznej w modelu UNB3m. 

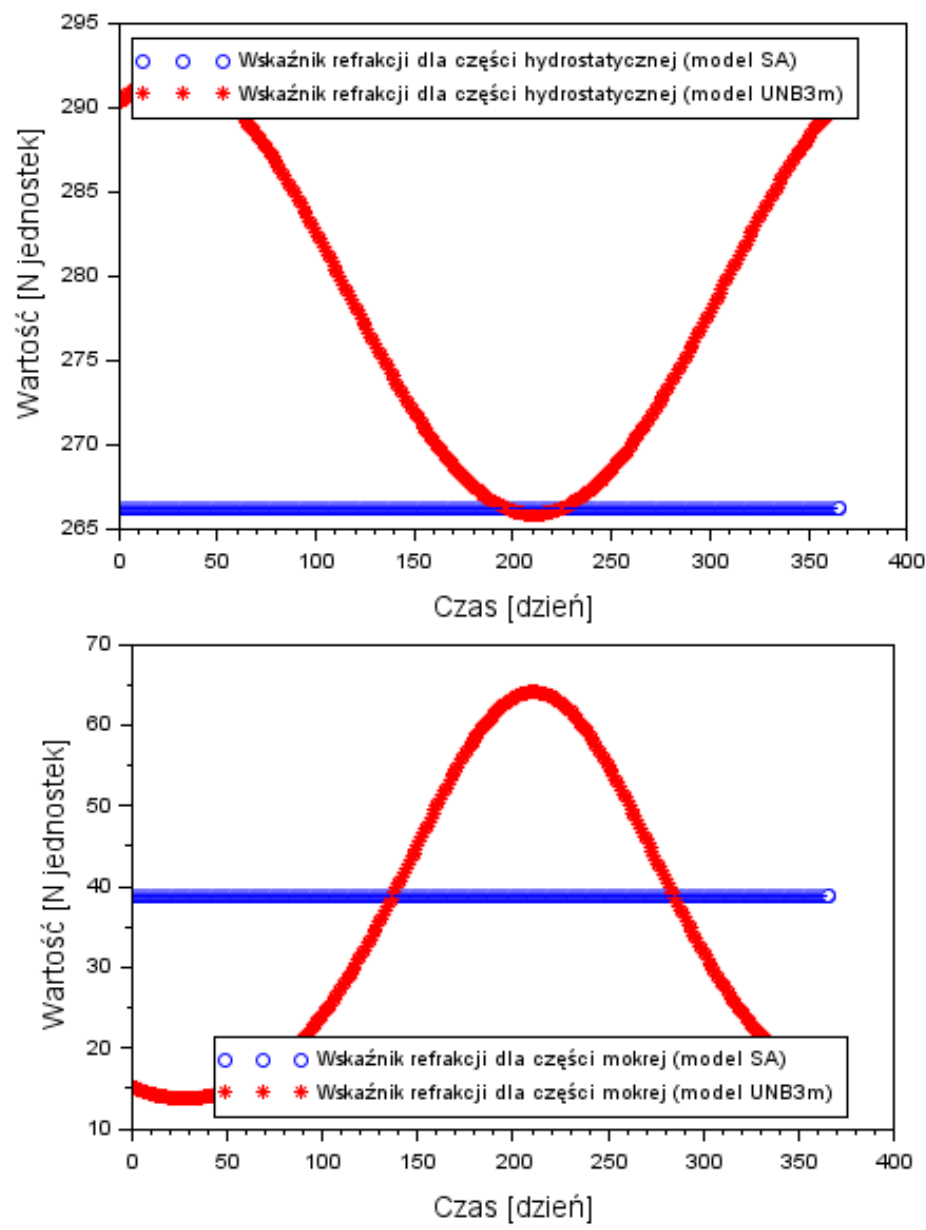

Rys. 1. Refrakcyjność dla części mokrej oraz hydrostatycznej dla stacji REF1 GNSS z modelu SA oraz UNB3m

Ponadto w dolnej części rys. 1 przedstawiono wartości wskaźników refrakcji troposferycznej dla części mokrej na podstawie empirycznych modeli SA i UNB3m. Wartości wskaźników refrakcji troposferycznej dla części mokrej zostały przedstawione w cyklu rocznym. Należy zauważyć, że wskaźnik refrakcji troposferycznej dla części mokrej dla modelu SA jest stały w cyklu rocznym i wynosi ok. 39 jednostek. Model empiryczny SA zakłada stały przebieg wskaźnika refrakcji troposferycznej dla części mokrej przez okres wiosenny, letni, jesienny i zimowy. Wartość wskaźnika refrakcji troposferycznej dla części mokrej dla modelu UNB3m w cyklu rocznym zmienia się periodycznie. Największe wartości wskaźnika refrakcji troposferycznej dla części mokrej dla modelu UNB3m są 
zauważane w okresie letnim, zaś najmniejsze w okresie zimowym. W szczególności wartość maksymalna wskaźnika refrakcji troposferycznej dla części mokrej dla modelu UNB3m wynosi 54,1 jednostek, zaś odpowiednio wartość minimalna jest równa 13,8 jednostek. Ponadto wartość mediany dla wskaźnika refrakcji troposferycznej dla części mokrej w modelu UNB3m wynosi ok. 31 jednostek. W modelu UNB3m występują dwa minima wskaźników refrakcji troposferycznej dla części mokrej, tj. w okresie styczeń i luty, oraz w okresie grudniowym. Ponadto na przełomie czerwca i lipca występuje maksimum wskaźnika refrakcji troposferycznej dla części mokrej w modelu UNB3m. W okresie wiosennym występuje wzrost o ok. 50 jednostek wartości wskaźnika refrakcji troposferycznej dla części mokrej w modelu UNB3m. W okresie jesiennym występuje spadek o ponad 50 jednostek wartości wskaźnika refrakcji troposferycznej dla części mokrej w modelu UNB3m.

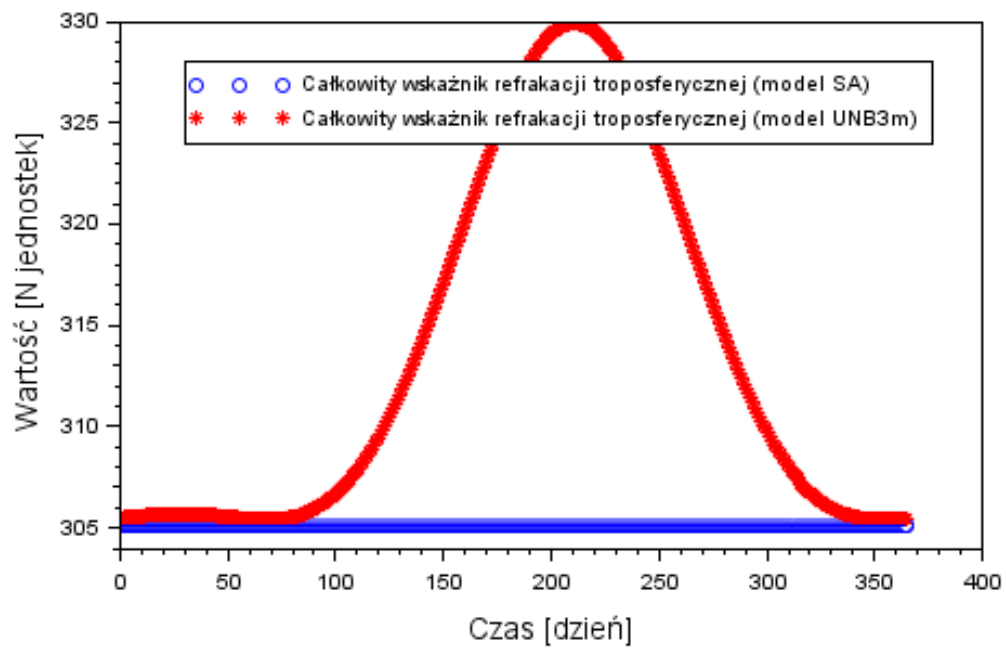

Rys. 2. Całkowita refrakcyjność dla stacji REF1 GNSS z modelu SA oraz UNB3m

Na rys. 2 przedstawiono wartości wskaźnika całkowitej refrakcji troposferycznej na podstawie empirycznych modeli SA i UNB3m. Wartości wskaźnika całkowitej refrakcji troposferycznej dla modelu SA i UNB3m zostały przedstawione w cyklu rocznym. Należy zauważyć, że wskaźnik całkowitej refrakcji troposferycznej dla modelu SA jest stały w cyklu rocznym i wynosi ok. 305,1 jednostek. Model empiryczny SA zakłada stały przebieg wskaźnika całkowitej refrakcji troposferycznej przez okres wiosenny, letni, jesienny i zimowy. Wartość wskaźnika całkowitej refrakcji troposferycznej dla modelu UNB3m w cyklu rocznym zmienia się periodycznie w czasie. Największe wartości wskaźnika 
całkowitej refrakcji troposferycznej dla modelu UNB3m są zauważane w okresie letnim, zaś najmniejsze w okresie zimowym. W szczególności wartość maksymalna wskaźnika całkowitej refrakcji troposferycznej dla modelu UNB3m wynosi 329,9 jednostek, zaś odpowiednio wartość minimalna jest równa 305,4 jednostek. Ponadto wartość mediany dla wskaźnika całkowitej refrakcji troposferycznej w modelu UNB3m wynosi ok. 309,3 jednostek. W modelu UNB3m występują dwa minima wskaźnika całkowitej refrakcji troposferycznej, tj. w okresie: styczeń, luty i marzec, oraz w grudniu. Ponadto na przełomie czerwca i lipca występuje maksimum wskaźnika całkowitej refrakcji troposferycznej w modelu UNB3m. W okresie wiosennym występuje wzrost o ok. 25 jednostek wartości wskaźnika całkowitej refrakcji troposferycznej w modelu UNB3m. W okresie jesiennym występuje spadek o ponad 25 jednostek wartości wskaźnika całkowitej refrakcji troposferycznej w modelu UNB3m.
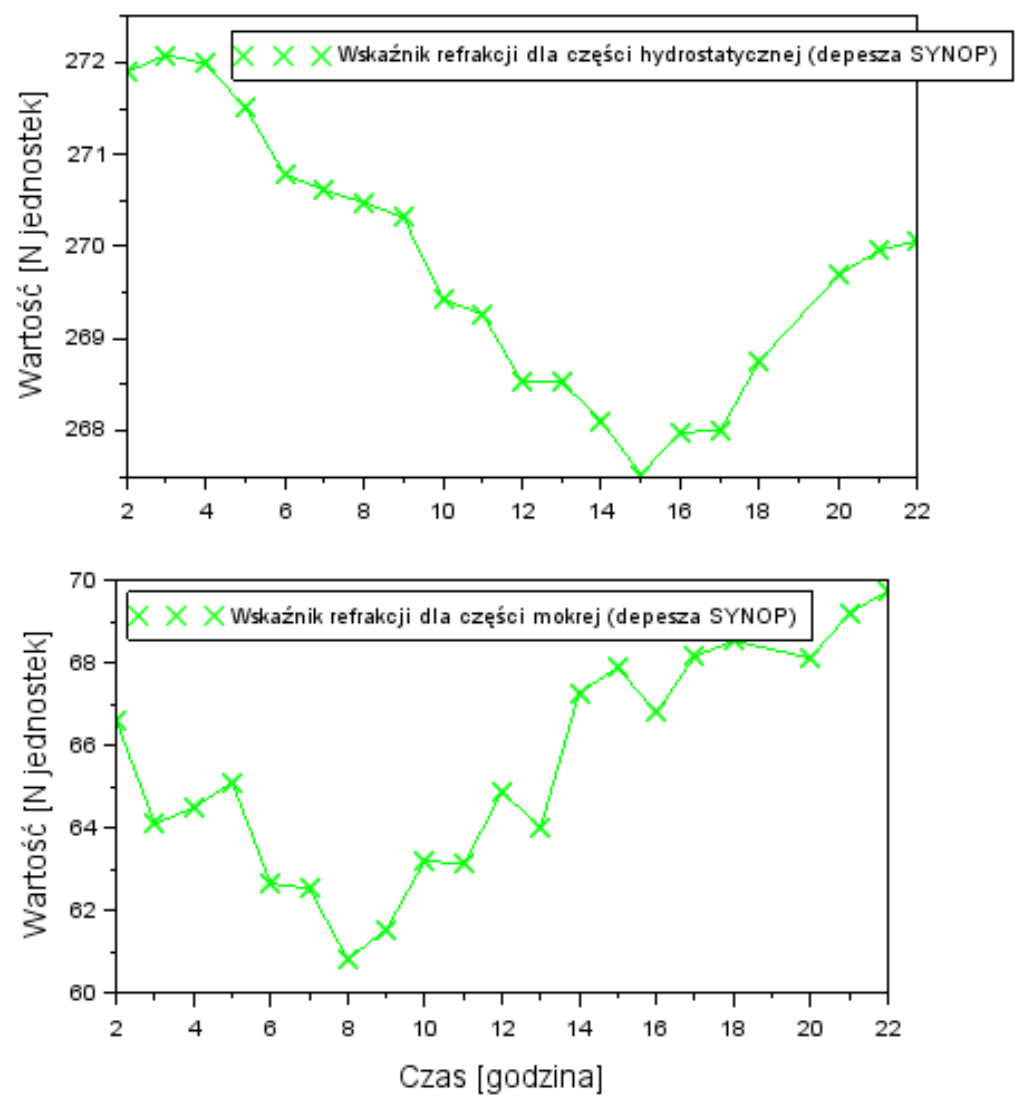

Rys. 3. Refrakcyjność części mokrej oraz hydrostatycznej dla stacji SYNOP 12490 
W drugim teście badawczym precyzyjnie wyznaczono wskaźniki refrakcji troposferycznej dla części hydrostatycznej i mokrej z użyciem danych meteorologicznych zarejestrowanych przez stację SYNOP Dęblin/Irena 12490. Stacja SYNOP Dęblin/Irena 12490 znajduje się w otoczeniu lotniska wojskowego EPDE w Dęblinie. Stacja SYNOP Dęblin/Irena 12490 jest cywilnym obiektem meteorologicznym, który stanowi własność Instytutu Meteorologii i Gospodarki Wodnej z siedzibą w Warszawie. Docelowe współrzędne geograficzne stacji SYNOP Dęblin/Irena 12490 są następujące: 51³3' N szerokość; 2151' E długość; $124 \mathrm{~m}$ wysokość nad poziomem morza. Przykładowe obliczenia numeryczne wskaźników refrakcji troposferycznej dla części hydrostatycznej i mokrej zostały wykonane dla dnia 1 czerwca 2010 r. Trzeba nadmienić, że wskaźniki refrakcji troposferycznej dla części hydrostatycznej i mokrej zostały wyznaczone na potrzeby wykonywanego $\mathrm{w}$ tym dniu eksperymentu lotniczego $\mathrm{w}$ ramach implementacji techniki satelitarnej GNSS dla procedur podejścia samolotu Cessna 172 do lądowania na lotnisku wojskowym w Dęblinie [3]. Określenie stanu troposfery w tym dniu było niezwykle potrzebne w celu utrzymania osłony meteorologicznej dla wykonywanych operacji lotniczych na lotnisku wojskowym EPDE w Dęblinie. Dane meteorologiczne dla stacji SYNOP Dęblin/Irena 12490 zostały wygenerowane z serwisu internetowego www.ogimet.com [10].

W górnej części rys. 3 pokazano dzienną zmianę wskaźnika refrakcji troposferycznej dla części hydrostatycznej, wyznaczoną na podstawie danych zarejestrowanych przez sensor meteorologiczny na stacji SYNOP Dęblin/Irena 12490 w dniu 01.06.2010. Minimalna wartość wskaźnika refrakcji troposferycznej dla części hydrostatycznej w dniu 01.06.2010 wyniosła 267,5 jednostek o godzinie 15 czasu UTC, zaś maksymalna wyniosła 272,1 jednostek o godzinie 03 czasu UTC. Ponadto średnia wartość wskaźnika refrakcji troposferycznej dla części hydrostatycznej w tym dniu wyniosła 269,7 jednostek, zaś mediana jest równa 269,8 jednostek. Od godziny 02 UTC do godziny 15 UTC wyraźnie widać, że wskaźnik refrakcji troposferycznej dla części hydrostatycznej stale maleje na podstawie danych meteorologicznych z depeszy SYNOP. Z kolei od godziny 15 UTC do godziny 22 UTC można stwierdzić, że wskaźnik refrakcji troposferycznej dla części hydrostatycznej stale rośnie na podstawie danych meteorologicznych z depeszy SYNOP. Należy zaznaczyć, że o godzinie 01, 19 i 23 sensor meteorologiczny na stacji SYNOP Dęblin/Irena 12490 nie zapisał żadnych danych liczbowych dotyczących parametrów troposfery $(p, T, e)$ i w związku z tym nie było możliwe wyznaczenie wskaźnika refrakcji troposferycznej dla części hydrostatycznej. W dolnej części rys. 3 pokazano dzienną zmianę wskaźnika refrakcji troposferycznej dla części mokrej, wyznaczoną na podstawie danych zarejestrowanych przez sensor meteorologiczny na stacji SYNOP Dęblin/Irena 
12490 w dniu 01.06.2010. Minimalna wartość wskaźnika refrakcji troposferycznej dla części mokrej w dniu 01.06.2010 wyniosła 60,8 jednostek o godzinie 08 czasu UTC, zaś maksymalna wyniosła 69,8 jednostek o godzinie 22 czasu UTC. Ponadto średnia wartość wskaźnika refrakcji troposferycznej dla części mokrej w tym dniu wyniosła 65,4 jednostek, zaś mediana jest równa 65 jednostek. Od godziny 02 UTC do godziny 08 UTC wyraźnie widać, że wskaźnik refrakcji troposferycznej dla części mokrej stale maleje na podstawie danych meteorologicznych z depeszy SYNOP. Z kolei od godziny 08 UTC do godziny 22 UTC można stwierdzić, że wskaźnik refrakcji troposferycznej dla części mokrej stale rośnie na podstawie danych meteorologicznych z depeszy SYNOP. Należy zaznaczyć, że o godzinie 01, 19 i 23 sensor meteorologiczny na stacji SYNOP Dęblin/Irena 12490 nie zapisał żadnych danych liczbowych dotyczących parametrów troposfery $(p, T, e)$ i w związku z tym nie było możliwe wyznaczenie wskaźnika refrakcji troposferycznej dla części mokrej.

Na rys. 4 pokazano dzienną zmianę wskaźnika całkowitej refrakcji troposferycznej, wyznaczoną na podstawie danych zarejestrowanych przez sensor meteorologiczny na stacji SYNOP Dęblin/Irena $12490 \mathrm{w}$ dniu 01.06.2010. Minimalna wartość wskaźnika całkowitej refrakcji troposferycznej w dniu 01.06.2010 wyniosła 331,3 jednostek o godzinie 08 czasu UTC, zaś maksymalna wyniosła 339,8 jednostek o godzinie 22 czasu UTC. Ponadto średnia wartość wskaźnika całkowitej refrakcji troposferycznej w tym dniu wyniosła 335,2 jednostek, zaś mediana jest równa 335,4 jednostek. Od godziny 02 UTC do godziny 08 UTC wyraźnie widać, że wskaźnik całkowitej refrakcji troposferycznej stale maleje na podstawie danych meteorologicznych z depeszy SYNOP. Z kolei od godziny 08 UTC do godziny 22 UTC można stwierdzić, że wskaźnik całkowitej refrakcji troposferycznej stale rośnie na podstawie danych meteorologicznych z depeszy SYNOP. Należy zaznaczyć, że o godzinie 01, 19 i 23 sensor meteorologiczny na stacji SYNOP Dęblin/Irena 12490 nie zapisał żadnych danych liczbowych dotyczących parametrów troposfery $(p, T, e)$ i w związku z tym nie było możliwe wyznaczenie wskaźnika całkowitej refrakcji troposferycznej. 


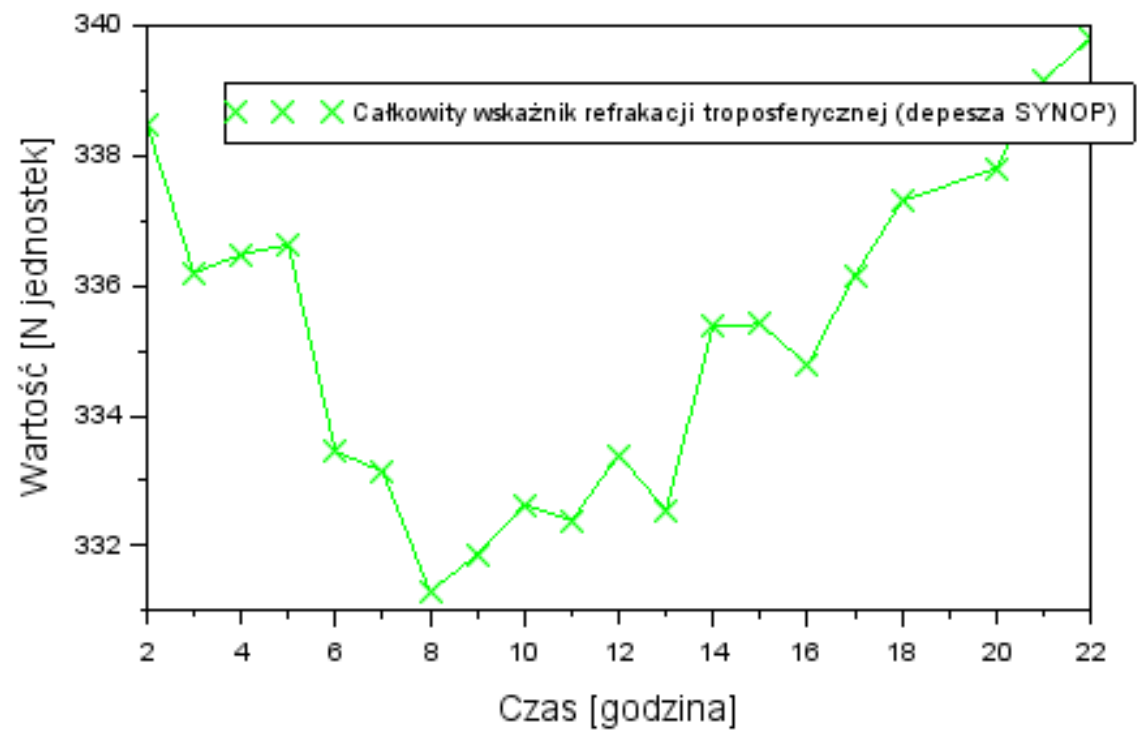

Rys. 4. Całkowita refrakcyjność dla stacji SYNOP 12490

\section{Wnioski}

W artykule przedstawiono rezultaty wyznaczenia wskaźników refrakcji troposferycznej dla obszaru lotniska wojskowego EPDE w Dęblinie. W szczególności przedstawiono wyniki wskaźników całkowitej refrakcji troposferycznej $N_{\text {trop }}$, wskaźników refrakcji troposferycznej dla części hydrostatycznej $N_{\text {hyd }}$, wskaźników refrakcji troposferycznej dla części mokrej $N_{\text {hyd }}$. Wskaźniki refrakcji troposferycznej zostały wyznaczone na podstawie empirycznych modeli troposfery oraz rzeczywistych danych meteorologicznych. W przypadku empirycznych danych meteorologicznych wykorzystano modele troposfery SA oraz UNB3m. Z kolei rzeczywiste dane meteorologiczne $(T, p, e)$ zostały zarejestrowane z użyciem stacji SYNOP Dęblin/Irena 12490. W obliczeniach wykorzystano podstawowe parametry metrologiczne, tj. temperaturę, ciśnienie i prężność pary wodnej.

\section{Podziękowania}

Podziękowania dla serwisu OGIMET za udostepnienie danych meteorologicznych. Artykut zostat sfinansowany przez Lotnicza Akademię Wojskowa w ramach badań statutowych na 2019 rok. 


\section{Literatura}

1. Adeyemi B., Emmanuel I.: Monitoring tropospheric radio refractivity over Nigeria using CM-SAT data derived from NOAA-15, 16 and 18 satellites. Indian Journal of Radio \& Space Physics. Vol. 40, 2011.

2. Bosy J.: Precise processing of satellite GPS observations in local networks located in mountain areas. Wydawnictwo Akademii Rolniczej we Wrocławiu. Nr 522, 2005 (in Polish).

3. Ćwiklak J., Krasuski K., Jafernik H.: Designation the velocity of Cessna 172 aircraft based on GPS data in flight test. Proceedings of $23^{\text {rd }}$ International Conference Engineering Mechanics 2017. Svratka, Czech Republic, 15-18 May 2017.

4. Dach R., Hugentobler U., Fridez P., Meindl M.: Bernese GPS software version 5.0. Astronomical Institute, University of Bern, 2007.

5. Ibeh G. F., Agbo G. A.: Estimation of tropospheric refractivity with artificial neural network at Minna, Nigeria. Global Journal of Science Frontier Research. Vol. 12, No. 1, Version 1.0 May 2012.

6. Krasuski K., Ćwiklak J., Jafernik H.: Verification of the precise position of the aircraft in air navigation based on the solution of the RTK-OTF technique. Journal of KONES. 2017, vol. 24, no. 4, DOI: 10.5604/01.3001.0010.3126.

7. Kruczyk M.: GNSS tropospheric delay and its issue in research on state of atmosphere. Prace Naukowe Geodezja. Vol. 54, 2013 (in Polish).

8. Leandro R., Santos M., Langley R.: UNB Neutral Atmosphere Models: Development and Performance, Proceedings of ION NTM 2006, the 2006 National Technical Meeting of The Institute of Navigation, Monterey, California, 18-20 January 2006.

9. Schaer S.: Mapping and predicting the earth's ionosphere using global positioning system. Ph.D. thesis, Astronomy Institute, University Bern, Switzerland, 1999.

10. www.ogimet.com, current on 2019. 